\title{
THE PROGRAM FOR THE DEVELOPMENT OF THE FISHERIES OF THE DNIPROPETROVSK REGION
}

\section{Novitskyi R. O., Bajdak L. A.}

\section{INTRODUCTION}

The concept of fish production in natural reservoirs and complexes of Ukraine lies within the framework of the program of integrated fish production technologies in agrohydrocenoses.

This chapter is devoted to the problem of integrated use of reservoir resources (algae, zooplankton, benthos) for obtaining economically viable protein products (fish and fish stocking material). The objective of the research and generalisations is to suggest the methods of fuller capacity utilisation of regional aquatic resources, to offer systemic approaches to industrial introduction.

Fish farming is one of the main suppliers of whole protein. Fish is a valuable, physiologically important food containing full proteins with a set of almost all essential amino acids, enzymes, as well as a significant amount of mineral elements (potassium, calcium, magnesium, phosphorus, ferrum, etc.).Fish lipids are characterised by high levels of biologically active polyunsaturated fatty acids and low levels of cholesterol, which makes fish dietary food that is recommended for people with cardiovascular disease. Fish products are a necessary component of diet for the people living in environmentally hazardous areas, such as the Dnipropetrovsk region.

Aquaculture in Ukraine, according to the State Agency of Fisheries of Ukraine, there are 7,850 reservoirs in operation with the total area of the water surface over 108,689 ha (i.e. on average for one region there are 327 basins of $4,528.7$ ha) and 513 reservoirs operating in SCFF (Special Commercial Fish Farms) mode of total area of 134,378 (i.e. on average there are 21.4 basins of SCFF area 4,528.7 ha) ${ }^{1}$.

The fish-farming complex in the Dnipropetrovsk region is composed of 230 water bodies with the area of 6,241.19 hectares, which are involved in aquaculture and 24 SCFF water bodies of a total area of 7,706 ha, with a total potential capacity of producing 2,399 tons of fish.

\footnotetext{
${ }^{1}$ Гринжевський М.В. Аквакультура України. К., 1998. 364 с.
} 
The analysis of retrospective stock materials of hydrochemical indicators of water quality in the ponds in the Dnipropetrovsk region, as well as of the research carried out by us has shown a significant variability of these indicators.

In the ponds of the main fish-breeding fund of the region, operating in SCFF (Zelenodolskryba LLC, Krivorizhryba LLC, Krynychky Fish Farm LLC, Petrykivka Fish Farm PrJSC), the chemical composition of water considerably depends on the quality of water supply sources, hydrological regime of ponds, as well as on the conditions of their operation. Thus, the Taromske department of Karachunivske Fish Farm LLC receives water from the Dniprovsky (Zaporizhzhia) reservoir, Zelenodolskryba LLC and Kryvorizhriba LLC - from the Kakhovka reservoir through the Dnipro-Kryvyi Rih Channel. According to quality indicators, the water meets all regulatory requirements. Petrykivka Fish Farm PrJSC and Krynychky Fish Farm LLC receive water from the river Oril and from the river Mokra Sura. The mineralisation is slightly increased here, sometimes reaching $1.5 \mathrm{~g} / \mathrm{dm}^{3}$.

The fishing potential of the Dnipropetrovsk region is quite significant, but it has been achieved to the extent of no more than $30 \%$. According to the studies carried out by scientific research (Dnipro State Agrarian and Economic University, Oles Honchar Dnipro National University, etc.) and production institutions of the region, a 5-time increase in the volumes of production of valuable fish products in the region, for a period of up to 5 years, is quite possible. According to statistics data, the average fish capacity of the Dnipro reservoir is $25 \mathrm{~kg} / \mathrm{ha}$, of medium reservoirs (Pivdenne, Karachunivske, Makortivske, etc.) $-20.8 \mathrm{~kg} / \mathrm{ha}$, the fish capacity of small reservoirs is not taken into account at all, since catches of fish in these waters are not registered. No statistics available. At the same time, the potential fish capacity of the Dnipro reservoir is at least $150-200 \mathrm{~kg} / \mathrm{ha}$, of medium and small reservoirs - not less than $200-300 \mathrm{~kg} / \mathrm{ha}$.

The generally accepted physiological standard of fish consumption worldwide, per person, is $20 \mathrm{~kg}$ per year, of which about one half falls on freshwater fish. In Ukraine, today this figure is $14 \mathrm{~kg}$, and in the Dnipropetrovsk region $-6-8 \mathrm{~kg}$ per person, i.e. 2.5-3 times less than normal.

Disorder in management and the absence of effective control over the state of water objects led to the threat of an imbalance of hydrological systems functioning in terms of environment. Contradictions of regulatory framework, the lack of overall trend of fish-breeding process 
in the region, the ecological state of water bodies both within the entire country and in the Dnipropetrovsk region, have resulted in extremely low efficiency of fish-farming utilisation of most water bodies of the Dnipropetrovsk region.

At the same time, the experience of the industry production and research institutions of the region allows to argue that at least 5-time increase in production of valuable fish products within the short term (up to 5 years) is quite possible. The main reason for the low efficiency of the fish-breeding in the Dnipropetrovsk region is the lack of a general strategy for the development of the fish industry of the region, as an integrated model of action aimed at achieving the goals of the industry or enterprise. To increase the production of fish-farming industry of the Dnipropetrovsk region it is necessary to take a complex of targeted and coordinated actions in different areas of economy, a gradual implementation of which is envisaged in the Strategy for the development of fisheries of the Dnipropetrovsk region. The strategy sets goals and objectives, determines the main areas of long-term activities taking into account natural and social and economic conditions, and also defines the areas of activities to ensure scientific and technological development of fish-breeding industry of the region. The objective of the Strategy is to set the main goal of strategic planning, to find the ways to achieve a new state of the fish industry, to increase the volumes and improve competitiveness of products based on the use of natural and resource potential and the established priorities of development of the fish industry. The main objective of the Strategy is to provide the residents of the region with a wide range of fish products, at affordable prices for people with different levels of income. The strategy was developed on the basis of proposals of state authorities, the Dnipro State Agrarian and Economic University, Departments of Environmental Safety and Water Management, research organizations, fish farms experts, users of aquatic resources, taking into account existing legislative and regulatory acts.

\section{Categories and characteristics of feeding sources for inland fishery water bodies}

Water storage basins. The main water fund of the Dnipropetrovsk region, which can be used for fish-breeding, is represented by three reservoirs on the Dnipro river (Dniprovske reservoir with the area of 48.0 thousand ha, Kakhovka reservoir - of about 40 thousand ha and Kamyanske reservoir - of about 28 thousand ha), 291 river, with the 
length of more than $10 \mathrm{~km}, 95$ medium-sized and small reservoirs, the total area of the water surface is 21 thousand ha, 1,457 lakes with a total area of 5,268 ha and 2,932 ponds with an area of 18.59 thousand ha. Most of these water objects have been traditionally used for fishbreeding since their creation (1930-1960). But this process in modern conditions has become rather disorderly, and a significant fish-farming fund of the state and the region is used only by $30 \%$.

The quality of the water supplying the fish-farming basins depends on the ecological status of the reservoirs and lakes. The studies carried out by the WBA department of the Dnipro State Agrarian and Economic University established the most common contaminants of the Dniprovske reservoir and rivers in its basin - nitrates, nitrites, nitrogen, biogenic and organic substances, heavy metals, oil products, surfactants, phenols, and radionuclides. A significant danger is represented by the tailing dumps on the banks of the river Konoplianka, where about 42 million tons of radioactive waste has been accumulated, from where natural radionuclides of technogenic origin get to the Dniprovske reservoir. An important factor in the pollution of the reservoirs is the agrarian complex. With the agricultural land surface wash-off a significant amount of nitrogen, phosphorus, potassium, organic matter, fertilizers, pesticides and microorganisms (animal and human pathogenic organisms) enter the water basins.

The ecological state of small reservoirs of the region has been studied to a lesser extent. In recent years, in a number of reservoirs (Karachunivske, Sholokhivske, Pivdenne, Kryvyi Rih State Regional Power Station), cases of diatoms and algal nuisance or the so-called "blooming" of water has become frequent, which not only hinders the fishing, but also causes toxicosis in fish and, in general, deteriorates sanitary and hygienic indicators of water and aquatic organisms. Particular attention is paid to the mass death of fish phytophages (silver carp), which is observed in spring almost annually in the reservoirs of the south-eastern region of Ukraine. It is assumed that the causes of this phenomenon are related to hydroecological conditions, but the solution of this problem requires a special comprehensive scientific research. Hydroecological conditions for fish farms built based on special projects and exclusively intended for fish production (Petrykivka, Kryvyi Rih, Krynychky, Taromske farms) correspond to the fishery standards (OST 15-372-87) by most of the indicators. A characteristic violation for almost all fish farms is the continuous exploitation of pond areas and the neglect of such important reclamation measure as ponds drying for the 
summer period. This leads to the silting of reservoirs and aquatic vegetation overgrowing, the deterioration of their sanitary and epizootic state ${ }^{2}$.

The main object of the fishing industry in the region is the Dniprovske water storage basin. Currently, the industrial fishing in the reservoir is carried out on an area of 6,336 ha $(27.6 \%$ of the total area of the basin). The catches of fish in the Dniprovske water storage basin has varied within quite a wide range for the last ten years: the minimum level is $105-130$ tons, the maximum - 357-412 tons, industrial fishing capacity varied from $4.6 \mathrm{~kg} / \mathrm{ha}$ to $14 \mathrm{~kg} / \mathrm{ha}$. Existing operation pattern of the Dnipro HPP and Kamyanske HPP, high level of pollution of municipal, industrial and agricultural enterprises, operation of water intake structures, irreversible water consumption, difficult situation with natural spawning grounds, recreational fishing and poaching caused a rather stressed general state of ichthyocenosis of the Dniprovske storage basin. On the other hand, the food potential of the reservoir is at a high level, especially for herbivorous fish, which causes a fairly high overall biological capacity of the pond. This implies an increase in the potential fish capacity of the reservoir to $30-40 \mathrm{~kg} / \mathrm{ha}$ and an annual catch of fish of about $600-800$ tons $^{3,4}$.

The fishery in the Dnipro reservoir is based only on the natural reproduction of fish populations (except for the silver carp and partially common carp), the level of which is insufficient and does not correspond to the resources of the food potential in the basin. Increased productivity of industrial fish fauna in the reservoir is only possible at the annual stocking it with fish seed in sufficient quantities, which should be determined by the scientific annual research.

The key position in the fishing industry of the Dnipropetrovsk region is occupied by carp species of fish, the production of which exceeds $80 \%$. In recent years there has been a tendency of expansion of the

${ }^{2}$ Новіцький Р. О. Масштаби, спрямованість та наслідки інвазій чужорідних видів риб у дніпровські водосховища. Автореф. дис. ... д-р біол. наук: 03.00.10. Київ: ІГ НАН України, 2019. 41 с.

${ }^{3}$ Сухойван П.Г., Вятчанина Л.И. Рыбное население и его продуктивность. $B$ кн.: Беспозвоночные и рыбы Днепра и его водохранилищ. К.: Наукова думка, 1989. C. 136-173.

4 Dvoretskyi A. I., Baidak L. A. Fisheries development strategy of Dnipropetrovsk region. Science and technology bulletin of biosafety and environmental control of Agro-industrial complex. 2018. Vol. 6 (1). P. 6-14. 
species diversity in fish breeding by using previously naturalised species: canal catfish, red-finned mullet and others.

Among the aquatic living resources of the Dniprovske water storage reservoir, in addition to fish, crayfish are also of industrial importance. Their catch values are unstable $(0.001 \mathrm{t}-0.391 \mathrm{t})$ and depend on many factors, both biotic and abiotic. To increase the catch of this extremely valuable food object, it is necessary to carry out a complex of sciencebased melioration measures.

The annual total catches of fish in small reservoirs (Karachunivske, Pivdenne, the heat sink of Kryvyi Rig TPP, Makorty, Khrystoforivske) over the past ten years amounted to an average of 160 tons. When carrying out a complex of reclamation measures, annual stocking with traditional species of fish and introductions of new species, as well as effective regulation of fishing, it is possible to achieve a 2-3 time increase in the volume of fish catch from small reservoirs.

Rivers. River Oril - left tributary of the river Dnipro. Observation of qualitative indicators of the river is carried out quarterly along the cross section in the village of Tsarychanka.

In conditions of human-induced pollution, it is important to obtain information on the state of surface waters of fisheries, being an integral part of the aquatic ecosystem, habitats of hydrobionts and a source of drinking water supply. The Oril River is referred to the category of relatively clean reservoirs. In the Dnipropetrovsk region, there is no sewage discharge from industrial enterprises to the river. In terms of an integral indicator of water quality -4.4 , surface water of Oril river is classified as «Satisfactory» grade III, «Satisfactory» 4 category;

The situation in the basin of the river Oril was particularly tense in the year 2013.

In recent years, the hydrological state of the river Oril significantly deteriorated due to the various man-made and natural factors combined. In addition, the climatic conditions of recent years - the duration of a dry period and heat complicated the hydrological regime of the river Oril and flood plains.

The Mokra Sura river is significantly affected by the industrial enterprises of the city of Dnipro (Pivdenmash OJSC and Dnipropres) and household waste water.

In terms of the ionic composition the water in the river Mokra Sura is of sulfate-hydrocarbonate class, sodium-magnesium group, type two. Due to human-induced impact, the water quality of the river was unstable and considerably deteriorated in the summer: during this 
stressful period, the content of dissolved oxygen in water decreased to $1.6 \mathrm{mg} / \mathrm{dm}^{3}$, which was $19.5 \%$ of saturation, $\mathrm{pH}$ - to 7.0 , the free carbon dioxide content increased to $8.8 \mathrm{mg} / \mathrm{dm}^{3}$; organic matter reached significant concentrations ( $\left.\mathrm{PO}-13.1 \mathrm{mg} / \mathrm{dm}^{3}\right)$ and especially biogenic elements: ammonium ions - up to $0.8 \mathrm{mg} / \mathrm{dm}^{3}$, nitrites to $0.111 \mathrm{mg} / \mathrm{dm}^{3}$, nitrates - up to $2 \mathrm{mg} / \mathrm{dm}^{3}$, phosphates - up to $0.5 \mathrm{mg} / \mathrm{dm}^{3}$. The availability of a significant amount of nutrients (nitrogen and phosphorus) contributed to the development of coastal and aquatic vegetation and characterised the river as a polytrophic reservoir ${ }^{5}$.

The content of inorganic forms of nitrogen was also characterised by a wide range of values. For example, for ammonia nitrogen - from 0 to $1 \mathrm{mg} / \mathrm{dm}^{3}$. On several sites (river Mokra Sura) there was an excess of fish-farming MPC $\left(0.5 \mathrm{mg} / \mathrm{dm}^{3}\right)$. The maximum concentration of ammonium nitrogen (up to $1.2 \mathrm{mg} / \mathrm{dm}^{3}$ ) is reached in summer in the bottom layers, where the products of primary mineralisation of organic matter are accumulated, and their subsequent oxidation is deteriorated due to the lack of oxygen. The accumulation of $\mathrm{NH}_{4}{ }^{+}$ions in the aquatic environment in summer may be due to several reasons. First, at low concentrations of dissolved oxygen, the process of nitrification is significantly slowed down - the oxidation of ammonia to nitrites and nitrates by nitrification bacteria. Secondly, the processes of bacterial decomposition of organic substances with the release of ammonia nitrogen are intensified in the summer. Thirdly, the deficit of dissolved oxygen should be considered as an important factor in increasing the migration of $\mathrm{NH}_{4}{ }^{+}$ions from bottom sediments in anaerobic conditions. Thus, high concentrations of ammonium nitrogen in water in the studied areas of the reservoir, on the one hand, indicate human-induced pollution, and on the other hand, it is the cause and consequence of low oxygen content, the interaction with which gives more oxidized forms of nitrogen.

\section{Factors for fish capacity of the reservoirs \\ Water quality}

Hydrochemical characteristic. In addition to the ponds of the main fish-breeding fund of the region, operating in SCFF mode (data on water quality is given in Table1) in the Dnipropetrovsk region, there are the

5 Запорожское водохранилище / А.И. Дворецкий, Ф. П. Рябов, Г.П. Емец и др. Д.: Изд-во ДНУ, 2000. 172 с. 
ponds that do not operate in the SCFF mode and are used mainly for recreational purposes.

These ponds are divided into the following types:

1. Ponds fed from the atmosphere - «atmospheric», located in the upper valleys, are filled with melt water or the waters of summer showers and isolated from groundwater.

2. Ponds fed by the ground and underground water.

3. Ponds in wet gullies, on springs or in riverbeds.

In «atmospheric» ponds, after filling in the period of spring water, a moderate mineralization of water is retained not exceeding $500 \ldots 800$ $\mathrm{mg} / \mathrm{dm}^{3}$ for many years. In terms of chemical composition, they usually belong to the hydrocarbon class, calcium group (rarely - calciumsodium), type one or two.

Table 1

\section{The main hydrochemical indicators of water quality of ponds operating in the SCFF}

\begin{tabular}{|c|c|c|c|c|c|c|c|}
\hline \multirow[b]{2}{*}{ № } & \multirow[b]{2}{*}{$\begin{array}{c}\text { Indicators } \\
\text { of water quality }\end{array}$} & \multirow[b]{2}{*}{ 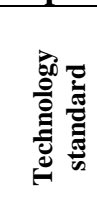 } & \multicolumn{5}{|c|}{ Ponds } \\
\hline & & & 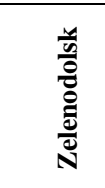 & 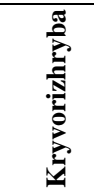 & 赵 & $\frac{\frac{\pi}{4}}{\sum^{\frac{\pi}{2}}}$ & \\
\hline 1 & $\mathrm{pH}$ & $7.0-8.5$ & $6.8-7.9$ & $7.0-7.9$ & $7.2-7.4$ & $7.0-9.2$ & $7.0-7.2$ \\
\hline 2 & $\begin{array}{c}\text { Dissolved oxygen, } \\
\mathrm{mg} / \mathrm{dm}^{3}\end{array}$ & $6.0-8.0$ & $6.0-10.0$ & $\begin{array}{l}6.00- \\
10.38 \\
\end{array}$ & $3.4-8.55$ & & $6.00-8.73$ \\
\hline 4 & $\mathrm{NH}_{4}{ }^{+}, \mathrm{mg} \mathrm{N} / \mathrm{dm}^{3}$ & 2.0 & $\begin{array}{l}<0.05- \\
0.21\end{array}$ & $\begin{array}{c}0,05- \\
0,26\end{array}$ & $\begin{array}{c}, 0,05- \\
0,49\end{array}$ & $0,05-0,11$ & $0,10-0,18$ \\
\hline 5 & $\mathrm{NO}_{2}{ }^{-}, \mathrm{mgN} / \mathrm{dm}^{3}$ & 0.1 & $\begin{array}{l}0.04- \\
0.05 \\
\end{array}$ & $\begin{array}{l}0,05- \\
1,00\end{array}$ & $0,05-0,25$ & $\begin{array}{c}\text { відсутн.- } \\
0,5 \\
\end{array}$ & $\begin{array}{c}\text { відсутн. } \\
-0,05 \\
\end{array}$ \\
\hline 6 & $\mathrm{NO}_{3}{ }^{-}, \mathrm{mgN} / \mathrm{dm}^{3}$ & 2.0 & $\begin{array}{l}<0.05- \\
2.09 \\
\end{array}$ & $\begin{array}{l}1.53- \\
4.21 \\
\end{array}$ & $<0.5-1.36$ & $<0.1-5.33$ & $0.96-1.00$ \\
\hline 7 & $\mathrm{PO}^{-3}{ }_{4}, \mathrm{mgP} / \mathrm{dm}^{3}$ & & $0.2-0.22$ & $\begin{array}{l}<0.02- \\
0.19\end{array}$ & $\begin{array}{l}<0.02- \\
0.23\end{array}$ & $0.05-0.10$ & $0.05-0.09$ \\
\hline 9 & $\mathrm{Ca}^{2+}, \mathrm{mg} / \mathrm{dm}^{3}$ & & 66.79 & $\begin{array}{l}84.76- \\
96.14\end{array}$ & 84.16 & $\begin{array}{l}61.73- \\
135.41\end{array}$ & 47.57 \\
\hline 11 & $\begin{array}{c}\text { General hardness, } \\
\text { mg-eq } / \mathrm{dm}^{3}\end{array}$ & & $5.7-6.09$ & $\begin{array}{c}6.80- \\
9.19 \\
\end{array}$ & 19.1 & $5.96-8.90$ & $3.74-9.00$ \\
\hline 13 & $\mathrm{SO}_{4}^{2-}, \mathrm{mg} / \mathrm{dm}^{3}$ & & 103.90 & 361.3 & 800.27 & $\begin{array}{c}157.4- \\
538.0\end{array}$ & 38.68 \\
\hline 14 & $\mathrm{Na}^{+}+\mathrm{K}^{+}, \mathrm{mg} / \mathrm{dm}^{3}$ & & 53.83 & 143.91 & $2,27.14$ & 272.55 & \\
\hline 15 & $\begin{array}{c}\text { Mineralization } \\
\text { (amount of ions), } \\
\mathrm{mg} / \mathrm{dm}^{3}\end{array}$ & & 456.67 & 918.87 & $1,698.46$ & $\begin{array}{l}493.0- \\
1.231 .8\end{array}$ & 274.00 \\
\hline
\end{tabular}


Based on the above data, it can be concluded that hydro-chemical indicators of water quality of both ponds operating in SCFF mode (Zelenodolskryba LLC, Kryvorizhryba LLC, Krynychky Fish Farm, Petrykivka PrJSC), and the ponds recreational purposes, mostly to meet the regulatory requirements.

Radioecology, natural and artificial radionuclides. Studies have been conducted of the content of natural $\left({ }^{226} \mathrm{Ra},{ }^{232} \mathrm{Th},{ }^{40} \mathrm{~K}\right)$ and artificial $\left({ }^{137} \mathrm{Cs},{ }^{90} \mathrm{Sr}\right)$ radionuclides in water and bottom sediments in the tissues of most common types of fish in the ponds of the Dnipropetrovsk region, the main fishery fund of the region, operating in the SCFF mode (Petrykivka Fish Farm PrJSC, Kryvorizhryba LLC, etc.).

Sampling of water, bottom sediments and fish, preparation for radiospectrometric testing was conducted in accordance with the common methods for measuring the radionuclides content.

The content of radionuclides was measured on a scintillation gammaray spectrometer SEG-001 «AKP-S» and a beta-ray spectrometer SEB-01-150 in a certified laboratory.

The quality of surface waters in terms of environmental criteria is estimated according to DSTU 4808:2007 (Hygienic and environmental requirements for water quality and selection rules).

As a result of the conducted research the following generalized data on the ponds of the above mentioned fish farms were obtained:

Petrykivka Fish Farm PRJSC. The content of natural radionuclides $\left({ }^{226} \mathrm{Ra},{ }^{232} \mathrm{Th},{ }^{40} \mathrm{~K}\right)$ in water: ${ }^{226} \mathrm{Ra}$ was $8.2 \mathrm{~Bq} / \mathrm{l}$, ${ }^{232} \mathrm{Th}-5.2 \mathrm{~Bq} / \mathrm{l},{ }^{40} \mathrm{~K}-28.2 \mathrm{~Bq} / \mathrm{l}$, in bottom sediments $-{ }^{226} \mathrm{Ra}-8.7$ $\mathrm{Bq} / \mathrm{kg},{ }^{232} \mathrm{Th}-14.2 \mathrm{~Bq} / \mathrm{kg},{ }^{40} \mathrm{~K}-198.0 \mathrm{~Bq} / \mathrm{kg}$; in fish $-{ }^{226} \mathrm{Ra}-36.8$ $\mathrm{Bq} / \mathrm{kg},{ }^{232} \mathrm{Th}-28.9 \mathrm{~Bq} / \mathrm{kg},{ }^{40} \mathrm{~K}-20.2 \mathrm{~Bq} / \mathrm{kg}$.

The content of artificial radionuclides $\left({ }^{137} \mathrm{Cs},{ }^{90} \mathrm{Sr}\right) \quad-$ in water ${ }^{137} \mathrm{Cs}-0.32 \mathrm{~Bq} / 1,{ }^{90} \mathrm{Sr}-0.09 \mathrm{~Bq} / \mathrm{l}$, in bottom sediments ${ }^{137} \mathrm{Cs}$, amounted to $5.3 \mathrm{~Bq} / \mathrm{kg},{ }^{90} \mathrm{Sr}-2.2 \mathrm{~Bq} / \mathrm{kg}$, in fish ${ }^{137} \mathrm{Cs}$ was $0.9 \mathrm{~Bq} / \mathrm{kg}$, ${ }^{90} \mathrm{Sr}-0.04 \mathrm{~Bq} / \mathrm{kg}$.

Kryvorizhryba LLC. The content of natural radionuclides $\left({ }^{226} \mathrm{Ra}\right.$, $\left.{ }^{232} \mathrm{Th},{ }^{40} \mathrm{~K}\right)$ in water: ${ }^{226} \mathrm{Ra}$ was $3,33 \mathrm{~Bq} / 1,{ }^{232} \mathrm{Th}-3.06 \mathrm{~Bq} / \mathrm{l},{ }^{40} \mathrm{~K}-4.12$ $\mathrm{Bq} / \mathrm{l}$, in bottom sediments $-{ }^{226} \mathrm{Ra}-7.4 \mathrm{~Bq} / \mathrm{kg},{ }^{232} \mathrm{Th}-36.4 \mathrm{~Bq} / \mathrm{kg}$, ${ }^{40} \mathrm{~K}-182.0 \mathrm{~Bq} / \mathrm{kg}$; in fish: ${ }^{226} \mathrm{Ra}$ was $36,2 \mathrm{~Bq} / \mathrm{l},{ }^{232} \mathrm{Th}-26.6 \mathrm{~Bq} / \mathrm{l}$, ${ }^{40} \mathrm{~K}-31.8 \mathrm{~Bq} / \mathrm{l}$.

The content of artificial radionuclides $\left({ }^{137} \mathrm{Cs},{ }^{90} \mathrm{Sr}\right)$ - in water: ${ }^{137} \mathrm{Cs}-0.12 \mathrm{~Bq} / \mathrm{l},{ }^{90} \mathrm{Sr}-0.05 \mathrm{~Bq} / \mathrm{l}$, in bottom sediments ${ }^{137} \mathrm{Cs}-5.6$ $\mathrm{Bq} / \mathrm{l},{ }^{90} \mathrm{Sr}-1.5 \mathrm{~Bq} / \mathrm{l}$, in fish: ${ }^{137} \mathrm{Cs}-1.0 \mathrm{~Bq} / \mathrm{l},{ }^{90} \mathrm{Sr}-0.06 \mathrm{~Bq} / \mathrm{l}$. 
It should be noted that there is a tendency for seasonal fluctuations of radionuclide content in the aquatic environment and fish products of these farms. The data is now processed and will be published in the future.

Thus, summing up the data obtained, it can be concluded that the level of natural and artificial radionuclides in the aquatic environment of the above mentioned farms operating in the SCFF mode does not exceed the MPC for water used for fishery purposes. These data correlate with data on the content of radionuclides in bottom sediments.

The content of radionuclides in fish samples is lower than the permissible levels for fish as a food product in Ukraine DR-2006. Based on the data, it is possible to rate the fish products from these farms as acceptable for consumption.

\section{Natural fish capacity}

Phytoplankton. In the Dniprovske storage reservoir, the leading role in the autotrophic chain of water biotopes is played by phytoplankton. Through the energy and food chains, it forms structural and functional features of the Dnipro biota at various levels of its organisation: population and species, biocenotic and ecosystemic. The phytoplankton also plays a significant part in the photosynthetic aeration of the water column, in the creation of water quality, self-purification and selfpollution, in the processes of radionuclide migration.

The functioning of the phytoplankton of the Dniprovske reservoir is significantly affected by the large industrial complex of the Dnipro river region. In the areas with a clearly expressed effect of the agro-industrial complex, the quality of water significantly deteriorates and there are considerable changes in the composition of phytoplankton groups. The areas of the reservoir, where there are no large sources of pollution, are characterised by satisfactory water quality, a more diverse species composition of phytoplankton.

In general, retrospective analysis of sanitary and ecological indicators of surface water quality has a tendency to an increased degree of saprobity in the Dniprovske reservoir, as well as in all bodies of the water cascade. The analysis of the sapro-biological state of the Dniprovske storage basin according to the structural indices of phytoplankton basically characterises the water quality as corresponding to the $\beta$-mesosaprobic area. This is explained by the general deterioration of the ecological state of the region as a whole and the hydro-ecosystem of the storage reservoir, with a corresponding change and substitution in 
the structure of phytoplankton groups. Thus, the saprobity index rises towards the bottom of the reservoir, especially in summer. In autumn, the index of species biodiversity is noticeably decreasing.

Generalisation of long-term data in terms of the indicators of phytoplankton biomass of the Dniprovske reservoir demonstrated spacetime division of maximum productive indicators of dominant species in different parts of the algae. In the Dniprovske reservoir there is a tendency of reducing of quantitative indicators of phytoplankton development and its diversity in areas of maximum impact of humaninduced pollution.

A large variety of natural and anthropogenic factors with their considerable spatial-temporal dynamics predetermines «outbreaks» and «recessions» in the dynamics of production and the number of phytoplankton that are characteristic of the most contaminated areas of the reservoir and the tributaries. In relatively clean areas, the dynamics is more stable.

In the Dniprovske reservoir, the regularities of the development of the plankton chain of hydrobionts are determined by a set of hydrological, hydrochemical human-induced factors. The important aspects for microalgae blooming are the steady vertical stratification of water, a high level of illumination of the water surface, water temperature, increased biogenic load on the reservoir (blue-green algae actively develops at the TN:TP < 29), and according to many researchers, the activity of the Sun.

For the Dnipro reservoir, as well as for its tributaries, the algae are the main producers of organic matter and oxygen. Phytoplankton microalgae in the process of photosynthesis bind a significant amount of carbon, which helps to replenish the reserves of autochthonous organic compounds in the ecosystem of the reservoir and promote the cycle of nutrients. They play a major role in providing food for consumers. In addition, they play an important role in the processes of self-purification of water bodies, as they enrich the water with oxygen and intensify the processes of oxidation of organic pollutants and excess of organic substances of biogenic origin.

At the same time, in the periods of «blooming», the transparency of water decreases, as well as the oxygen content, which causes the mass fish mortality, and intensify the development of pathogenic flora. In addition, blue-green algae are producers of more than 60 types of low 
molecular toxic substances (algotoxins) ${ }^{6,7}$. Therefore, the development of plankton biomass in the reservoir has ambiguous consequences.

Since the Dniprovske reservoir is characterised by a number of water processes - hydrological, hydrophysical, hydrochemical, and hydrobiological, the water storage basin processes are not identical to those observed in other water bodies (rivers, lakes, etc.). The species composition and the range of dominant species in the same season are different for the reservoir and for the main tributaries (river Oril, river Samara, river Mokra Sura), although these tributaries are an important source of planktonic microorganisms in the storage basin. Many years of observation show that the hydrological factors in the reservoir are in many respects decisive for the patterns of development of the primary producers' structure.

Of the many factors influencing the development of phytoplankton, there are the factors that determine the trophism as well. The trophic conditions of the Dniprovske storage reservoir are formed mainly under the influence of the Kamyanske storage basin runoff and the surface runoff. In recent years, human-induced impact on the trophic conditions of the reservoir is being increasingly conditioned by the industry and utilities sewage, which is a source of both biogenes and chemical and radioactive contaminants.

In general, the numerical composition of the modern phytoplankton of the reservoir is characterised by considerable diversity (about 227 species), mainly due to green algae (85 species), diatoms (95 species) and blue-green algae (20 species) with well-defined seasonal dynamics: the largest number of species is observed in summer phytoplankton, and the minimum - In winter. Most often, in all areas of the reservoir and in the main tributaries (river Samara, river Mokra Sura, river Oril) the following species were found: Microcystys pusillum, Microcystys aeroginosa, Aphanizomenon flos - aquae, Oscillatoria planctonica, Cyclotella kuetzingiana, Cyclotella menenghiniana, Stephanodiscus hantzschii, Stephanodiscus binderanus, Melozira granulate, Melozira italica, Asterionalla Formosa, Chlamydomonas globosa, Scenoedesmus quadricauda, Pediastrum duplex, Pediasrum borianum, Coelastrum microporum. In the vast majority of cases, during

6 Бурмакин Е. В. Акклиматизация пресноводных рыб в СССР. Известия ГосНИОРХ. 1963. Т. 53. С. 2-317.

${ }^{7}$ Вовк П.С., Стеценко Л.И. Рыбы-фитофаги в экосистеме водохранилищ. К.: Наук. думка, 1985. 136 с. 
the spring and summer blooms, a development of two or three planktonic species, more often - of Microcystis, Anabaena, Aphanizomenon, Oscillatoria, Melosira, Cyclotella, is observed.

Development of fodder organisms. The zooplankton biomass has remained stable for years, and the number is increasing due to the replacement of large-sized forms with small ones. Reduction in the number of large-size forms of zooplankton (daphnia) causes a decrease in fish capacity. Of toxic substances, the main factor that inhibits the development of reservoir zooplankton and causes its structural and functional reorganisation, there are the petroleum products and certain heavy metals, and a stimulating factor is the number of bacterioplankton.

The biota structure is a reflection of the functional state of aquatic ecosystems and, at the same time, determines this state. The biota influences the processes of substance transformation and energy flow, the formation of water quality and the bioproductivity of reservoirs. Solving the problems of biological monitoring of surface water of various types requires the development of new theoretical, methodological and experimental approaches. It is worth noting, that the species composition of the bottom groups depends on the strength and degree of exposure of human-induced harmful factors. In low flow rivers, under the combined action of many factors, the biotopes become extinct (there so-called man-made deserts appear). In biotopically homogeneous rivers, the indication is carried out by changes in the structural and functional characteristics of the bottom groups. The benthic organisms have a rather definite spatial localisation, so their species composition and development period indicate the degree of human-induced influence ${ }^{8,9}$.

As a result of changes in the hydrological regime in a new reservoir, optimum conditions for the emergence and mass reproduction of invading organisms, such as the Dreissena polymorpha clam (Pall.), were formed. The mass reproduction of the zebra mussel, which in a short time settled in the reservoir, was first noted by P. O. Zhuravel in the paper «On the State of Some Representatives of the Mollusca and Crustacea Fauna in the Dnipro HPP Reservoir». The author noted that before the flooding of the rapids area of the Dnipro river, the zebra

8 Яковенко В. О., Дворецький А. I. Зоопланктон Дніпровського водосховища. Дніпропетровськ: Гамалія, 2012. 254 с.

9 Yakovenko V., Fedonenko O., Tushnytska N. Zooplankton and zoobenthos of the Mokra Sura river. Rybohospodarska nauka Ukrainy. 2017. 42(4), 19-32 DOI: $10.15407 /$ fsu2017.04.019 
mussel was relatively rare, which was explained by the hydrological regime of this part of the Dnipro and the living conditions of the shellfish. Starting from the year 1932, as P. O. Zhuravel noted, that is from the moment of filling the Dniprovske storage reservoir, the zebra mussel appeared in a noticeable amount. The author notes the fact that zebra mussel entered the water supply pipeline of hydroelectric power plant. The management of the Dnipro HPP was forced to clean the pipelines clogged with the valves of the zebra mussel. From our point of view, it is important to inform about the need of a special research on the Dnipro HPP for more effective means of controlling and prevention of spreading zebra mussel.

\section{Fish production}

Fish fauna and the whole range of ichthyological and fishery operations has occupied a leading position in studies of the Dnepropetrovsk hydrobiology experts since the foundation of the Dnipropetrovsk hydrobiological station. This was due to their practical significance and the acute need in fish products. Before the Dnipro HPP was built, on the rapids reach of the Dnipro river, more than 50,000 pounds of fish had been caught annually, of which up to 500 pounds accounted for sturgeon and over 500 pounds - for herring. Among the tributaries of the rapids reach of the Dnipro river, fishing was most noticeable in Samara (from the mouth to the city of Novomoskovsk), in the mouth of which there were anadromous and semianadromous species: beluga, sturgeon, herring, Black Sea roach and others. Serious researches of the rapids reach of the Dnipro river began in 1926-1927, when Dnipropetrovsk hydrobiological station was established. During the expeditions on the rapids area of the Dnipro river the knowledge of the structure of the ichthyofauna and the food reserve of fish were accumulated and systematized. The work of the personnel of the station, studying the composition of the fish fauna of the Middle Dnipro became the basis for the characteristics of the original fish fauna with further comparison of transformation during the Dnipro regulation. The most significant place in fisheries sector on the rapids area of the Dnipro river is occupied by such species as the nase, barb (barbel), burbot, asp, cyprinid, which lived directly on the rapids in large amounts and spawned there. In the papers by I.I. Korotkyi the details are given on the ichthyofauna of the rapids of the river Dnipro. He notes that if before the construction of the dam in the rapids area of the Dnipro river the rheophilous species of fish - a barb, a nase, a cyprinid, a chub, a burbot 
and others had been widespread, then after the dam construction limnophilic forms predominated - rutilus, bream, rudds and others. I.I. Korotkyi provides the list of 46 species and 1 subspecies of fish and ichthyoids living in the river among other fish of the rapids area of the river Dnipro. Some of them were anadromous and semianadromous forms: hausen, sturgeon, starry sturgeon, pontian herring, roach, vimba, Black Sea roach and others. According to I.Y. Syrovatskyi and P.K. Gudymovych (1927), F.F. Yegerman (1929), L.S. Berg (1948), S.P. Fedia (1952), P. G. Sukhoivan (1956), V.I. Vladymyrov, P.G. Sukhoivana and K. S. Bugay (1963), sturgeons and herring climbed much farther upstream the rapids for spawning, hausen and sterlet went especially far upstream the Dnipro river. Some other semianadromous fish (carps - roach, vimba, Black Sea roach and others) went to the rapids and upstream of the rapids for spawning. In the rapids part of the Dnipro river, some of the fish, the representatives of the Liman-Caspian complex fauna were the permanent residents: sterlet, carp gudgeon (5 species). Both anadromous and semianadromous fish slipped into the delta of the Dnipro river and to the coastal lake after spawning. As to the roach, F. F. Yegerman (1929) admitted that a part of its flock, apparently, spent winter in Zaporizhzhia fishing area. After the construction of the Dnipro HPP dam, the reservoir ichthyofauna has changed, as well as its species composition. The results of the study of the first stages of hydrofauna formation, including the ichthyofauna, in the conditions of regulation of the Dnipro rapids and the initial formation of the hydrological regime of the water storage reservoir are provided in the monograph by D. O. Svirenko «Dniprovske Water Storage Basin». The construction of the Dnipro reservoir worsened the conditions for the reproduction for many species, led to further simplification of the ichthyocenosis structure and its imbalance. Anadromous and semianadromous species become extinct, some rheophils of the newly created reservoir.

\section{Taxonomic diversity of fishes in water bodies within Steppe Prydniprov'ya}

Within Prydniprov'ya, the common cyclostomes and fish biodiversity

of Dnieper reservoirs is represented by one order of cyclostomes and 13 orders of bony fishes (20 families, 57 genera, and 75 species). Only 
Lampreys (Cyclostomata) order is represented by 1 family, 1 genus, and only Ukrainian brook lamprey (Eudontomyzon mariae) species ${ }^{10}$.

There used to be 6 species of sturgeons (Acipenseriformes) (7.9\% of all fish fauna species), and now it has only 2 species (2.6\%): indigenous species sturgeon Acipenser ruthenus, and alien species paddlefish Polyodon spatula, which is bred in the Zelenodol'sk CHP thermal reservoir and Petrykivka fish farm. At present, Herrings (Clupeiformes) order consists of three alien species: Black Sea shad Alosa pontica, Caspian shad A. caspia nordmanni, Black Sea sprat Clupeonella cultrivensis.

At different times, Salmonids (Salmoniformes) order consisted of 4 species into 2 families (salmon - Salmonidae and Whitefishes Coregonidae) and 2 orders (Salmo and Coregonus). The current species composition of this order consists of anadromous indigenous species such as Black Sea salmon Salmotrutta labrax which vanished in fish fauna after the Dnieper flow regulation.

Esociformes (Esociformes) order is monotypic genus with alone indigenous species - northern pike (Esox lucius).

The most taxonomically speciose is order of cyprinid fishes (Cypriniformes) consisteds of three families - Carps Cyprinidae, Hillstream Loaches Balitoridae and Eel Cobitidae. Today this order primarily consists of indigenous species ( 25 species). Another 6 species are alien species of invasive (stone moroco Pseudorasbora parva, Pontian shemaya Alburnus sarmaticus and common roach Rutilus rutilus) and introduced (Prussian carp Carassius gibelio, silver carp Hypophthalmichthys molitrix and bighead carp Aristichthys nobilis) origins. Indigenous species Dnieper barbel (Barbus barbus borystenicus) extincted from the fish fauna after construction of Kamyanske reservoir.

Catfishes (order Siluriformes) used to consist of one indigenous species: European wels (Silurus glanis). Today, it consists of 2 families: Eurasian freshwater catfishes Siluridae and North American freshwater catfishes Ictaluridae (channel catfish Ictalurus punctatus introduced and bred in fish farm ponds).

Mullet-like fishes (Mugiliformes), Anacanthini (Gadiformes), Pipefishes (Syngnathiformes) and killifishes (Cyprinodontiformes) consisted of one species. Only the Anacanthini included the indigenous

10 Біологічне різноманіття України. Дніпропетровська область. Круглороті (Cyclostomata). Риби (Pisces) / В. Л. Булахов, Р. О. Новіцький, О. Є. Пахомов, О. О. Христов. Д.: Вид-во Дніпропетр. ун-ту, 2008. 304 с. 
species - burbot Lota lota. The others belong to alien species. The invasive species are represented by Boier's sand smelt Atherina boueri and black-stripped pipefish Syngnathus abaster and introduced species mosquito fish Gambusia affinis, which are introducted in natural water bodies (mainly in floodplain lakes) and existed only to 1930 .

Order Gasterosteiformes includes 1 family Sticklebacks (Gasterosteidae) with two species: indigenous species - Southern ninespined sticlebacks (nine-spined sticlebacks) Pungitius platygaster and invasive species - three-spined sticlebacks Gasterosteus aculeatus.

Order Perciformes now includes 3 families with 11 genera and 16 species. Family Centrarchidae is represented by 1 invasive species pumpkinseed sunfish Lepomis gibbosus, which was intentionally introduced in the region water bodies in the 1980s by fish hobbyists.

In family Percidae 4 genera were registered. Genus Sander is presented by 2 species: indigenous species - European pikeperch Sander lucioperca and alien invasive species Volga zander Sander volgensis. Both orders Perca and Percarina compose of one species: indigenous species as river perch Perca fluviatilis, and invasive species - Azov percarina Percarina demidoffi. Genus Gymnocephalus previously included 2 indigenous species as ruffe Gymnocephalus cernuus is a dispersed species, and Don ruffe Gymnocephalus acerinus that have extincted in the region fish fauna in the late 1980s after regulation of Dnieper river.

Family Gobies (Gobiidae) is the most diverse among persh-like fishes; it includes 6 genera with 11 species. Indigenous species are monkey goby Neogobius fluviatilis, tube-nosed goby Proterorhinus marmoratus, and starry goby Benthophilus stellatus. Other Gobies, such as round goby Neogobius melanostomus, big-headed goby N. kessleri, racer goby N. gymnotrachelus, ratan goby N. ratan (genus Neogobius), knout goby Mesogobius batrachocephalus (genus Mesogobius), Brauner's tadpole-goby Benthophiloides brauneri (genus Benthophiloides), caucasian dwarf goby Knipowitschia caucasica and longtail dwarf goby K. longecaudata (genus Knipowitschia) are alien species of invasive origin, which entered in the Dnieper reservoirs from the Dnieper-Bug estuary.

Thus, during the $20^{\text {th }}$ and early $21^{\text {st }}$ centuries, cyclostomes taxonomic diversity had been unchanged, and fish taxonomic diversity had been permanently changed (Table 2).

Changes in fish species composition were caused by following: environmental (climatic) changes, shallowing of small rivers and lakes; 
human-made one: river flow regulation, rise of water mineralization due to pollution, introduction works.

In the modern time, the fish fauna of water bodies within steppe Prydniprovya (including the Dnieper water reservoirs) has 65 species: 40 indigenous species $(61.5 \%)$ and 25 alien species $(38.5 \%)^{11,12}$.

Table 2

\section{Dynamics of fish fauna diversity in the reservoirs of steppe zone of Ukraine; number of species}

\begin{tabular}{|c|c|c|c|c|c|}
\hline \multirow[b]{2}{*}{ Group of fish origin } & \multicolumn{5}{|c|}{ Period } \\
\hline & $\begin{array}{c}1^{\text {st }} \\
\text { (before } \\
\text { early } 20^{\text {th }} \\
\text { century) }\end{array}$ & $\begin{array}{c}2^{\text {nd }} \\
(1926- \\
1937)\end{array}$ & $\begin{array}{c}3^{\text {rd }} \\
(1938- \\
1955)\end{array}$ & $\begin{array}{c}4^{\text {th }} \\
(1950 \mathrm{~s}- \\
\text { late } \\
1970 \mathrm{~s})\end{array}$ & $\begin{array}{c}5^{\text {th }} \\
\text { (late } 1970 s- \\
\text { current } \\
\text { stage) }\end{array}$ \\
\hline Indigenous species: & 47 & 47 & 43 & 40 & 47 \\
\hline With them extincted & 0 & 4 & 3 & 0 & 7 \\
\hline Remained & 47 & 43 & 40 & 40 & 40 \\
\hline Alien species: & 0 & 9 & 23 & 25 & 28 \\
\hline Introduced & 1 & 4 & 8 & 8 & 11 \\
\hline At present & 1 & 6 & 4 & 0 & - \\
\hline Total & 1 & 6 & 8 & 8 & - \\
\hline Extincted & 1 & 2 & 0 & 0 & 3 \\
\hline Naturalized & 0 & 4 & 8 & 8 & 8 \\
\hline Invasive: & 0 & 5 & 15 & 2 & 17 \\
\hline For today & 0 & 5 & 10 & 17 & - \\
\hline Total & 0 & 5 & 15 & 17 & - \\
\hline Extincted & 0 & 0 & 0 & 0 & 0 \\
\hline Naturalized & 0 & 5 & 15 & 17 & 17 \\
\hline $\begin{array}{l}\text { At the end of the } \\
\text { period }\end{array}$ & 48 & 58 & 66 & 65 & 75 \\
\hline Left & 47 & 52 & 63 & 65 & 65 \\
\hline
\end{tabular}

Thus, for all the time 75 species have been registered in the water bodies of the region; forming of fish fauna was accounted for indigenous species $(62.7 \%)$ and alien species $(37.3 \%)$, including invaders $-14.6 \%$, and self-invaders $-22.7 \%$.

${ }^{11}$ Novitsky R. A., Hristov O. A., Kochet V. N., Bondarev D. L. Annotated list of fishes of the Dnieper Reservoir and its tributaries. Bulletin of DNU. Biology, Ecology. Issue 13, Vol. 1. Dnipropetrovsk: Publ. of DNU, 2005. P. 185-201.

12 Issues of the ecosystem services provided by animals under anthropogenic pressure within Ukrainian steppe: monogr. (2016). A. Y. Pakhomov et al. Vienna: East West Association for Advanced Studies and Higher Education GmbH. 160 p. 


\section{Environmental complexes and geographic types of cyclostomes and fish fauna}

Geographic types of fish fauna. Within the Dnieper reservoirs fish fauna is divided into six geographic types by its origin: widely distributed (fish widespread within the province), Ponto-Caspian, Mediterranean, Arctic, Amur (Far Eastern), American (Table 3).

Table 3

Geographic types of cyclostomes and fish in the reservoirs of the Lower and Middle Dnieper in the last 100 years (\% to the number of species in water bodies)

\begin{tabular}{|c|c|c|c|c|c|c|c|}
\hline \multirow{3}{*}{$\begin{array}{c}\text { Geographic } \\
\text { type }\end{array}$} & \multicolumn{6}{|c|}{ Aquatic ecosystems } & \multirow{3}{*}{$\begin{array}{c}\text { All } \\
\text { aquatic } \\
\text { ecosystems }\end{array}$} \\
\hline & \multicolumn{2}{|c|}{ River } & \multicolumn{2}{|c|}{ Lake } & \multicolumn{2}{|c|}{ Reservoirs } & \\
\hline & $\begin{array}{c}\text { Full- } \\
\text { flowing }\end{array}$ & $\begin{array}{c}\text { Low } \\
\text { water }\end{array}$ & Steppe & Forest & Dnieper & $\begin{array}{c}\text { Kryviy } \\
\text { Rih }\end{array}$ & \\
\hline \multicolumn{8}{|c|}{ Cyclostomata } \\
\hline Mediterranean & 100 & - & - & - & 100 & - & 100 \\
\hline \multicolumn{8}{|c|}{ Fish } \\
\hline $\begin{array}{c}\text { Widely } \\
\text { distributed }\end{array}$ & 28.9 & 31.8 & 48.4 & 38.4 & 30.5 & 27.7 & 30.7 \\
\hline Ponto-Caspian & 34.2 & 40.9 & 31.3 & 31.6 & 33.9 & 29.8 & 32.0 \\
\hline Mediterranean & 31.5 & 27.3 & 25.0 & 20.0 & 27.1 & 25.5 & 25.3 \\
\hline Arctic & 26 & - & - & - & 1.7 & 4.3 & 5.3 \\
\hline $\begin{array}{l}\text { Amur (far } \\
\text { Eastern) }\end{array}$ & - & - & - & - & 5.1 & 6.4 & 4.0 \\
\hline American & 2.6 & - & $5.3 *$ & $5.3^{*}$ & - & 6.4 & 2.7 \\
\hline
\end{tabular}

Note. *-Introduced extinct species mosquitofish (Gambusia holbrooki).

The Ponto-Caspian and widely distributed type of fish fauna occupy dominant position (respectively, $32.0 \%$ and $30.7 \%$ ), and Mediterranean type $(25.3 \%)$ is subdominant. Just dominant and subdominant types composed mainly of autochtonous fish fauna. Such pattern in the distribution of the dominant types and geographical subdomìnant fish fauna is observed also in different aquatic ecosystems. Arctic, Siberian and American types of fauna, except for one species (burbot Lota lota), mostly act as alien species with different variations of diversity, are presented in different water bodies. In the river systems Arctic and American types are consisted of only 1 species (by $2.6 \%$, respectively, Lota lota and Lepomis gibosus), and the Amur type is absent.

These three geographic types are absent in the low water river systems. The current lake ecosystems of these types are absent too, but in 
the $1930^{\text {th }}$ lakes with American type of fauna (mosquitofish Gambusia holbrooki) were occured in the region.

Within the Dnieper reservoirs, all six types of fauna are present, where the dominant group consists of widely distributed Ponto-Caspian and Mediterranean types (25-29.8\%), the remaining types - within 4.3-6.4\%. In the larger Dnieper reservoirs dominant and subdominant types of fauna consist of $91.5 \%$.

Amur type is represented by acclimatized species (grass carp Ctenopharyngodon idella) $5.1 \%$, and indigenous Arctic one includes only one species $-1.7 \%$.

A significant diversity of fish ecological complexes caused by different water ecosystems, such as small rivers, channel ways, ponds, the Dnieper reservoirs etc. Limnophiles occupy dominant position in the water bodies $(68.1 \%)$. Absolute majority of limnophiles are typical for the gally ponds, forest lakes, especially in the ponds of dead river arms $(89.5 \%)$, river bed ponds within rivers $(83.3 \%)$, low water ephemerical rivers $(81.8 \%)$, and in the arid lakes $(81.3 \%)$. Rheophilic and generative-rheophilic species both are $27 \%$, when the share of true rheophils is $20.8 \%$. The share of marine and brackish-water fishes is only $4.2 \%$. The true rheophils are found everywhere except the gally ponds. The largest number is observed in deep rivers $(37.5 \%)$ and in the Dnieper reservoirs $(23.3 \%)$. Proportion of rheophiles varies within $16.7-18.5 \%$ in the low water rivers, small reservoirs (Kryviy Rih type), in the lakes connected with rivers during the seasonal flood, and in the river ponds. Only in bayou lakes rarely connected with river this value is about $10.5 \%$. Generative-rheophils which gain in weight in lake-like reservoirs and carry eggs in the flow are presented only in reservoirs $(10.7-11.8 \%)$ and flood rivers $(7.8 \%)$.

\section{Current fish fauna of the Steppe Zone in Ukrainian water bodies}

By now, class Cyclostomes (Cyclostomata) is represented by only 1 species: Ukrainian brook lamprey (Eudonmyzon mariae), which belongs to family Petromyzonidae with order Lampreys (Petromyzoniformes) in the fauna of Steppe zone in Ukraine. In the 1930s, this species was firstly discovered by P. Zhuravel (Berg, 1949) in the Samara River, and at the present time it found in Orel' River near village Tzarichanka of the Dnipropetrovsk region.

Fishes (Pisces) are presented by only class of Bony fish (Osteichthyes), subclass Ray-finned Fishes (Actinopterygii) and two 
infraclasses: Chondrosteanes (Chondrostei) and Teleosts (Teleostei), which both comprise the 12 orders (Table 4).

Table 4

\section{Taxonomic composition and status of Cyclostomas and Fishes within Middle Dnieper and its tributaries}

\begin{tabular}{|c|c|c|c|}
\hline Taxa & Species and subspecies & Origin & $\begin{array}{c}\text { State of protection, } \\
\text { Red Data Book } \\
\text { of Ukraine / } \\
\text { Red Data Book } \\
\text { of Dnipropetrovsk } \\
\text { region }\end{array}$ \\
\hline 1 & 2 & 3 & 4 \\
\hline \multicolumn{4}{|c|}{ CLASS CYCLOSTOMATA - CYCLOSTOMES } \\
\hline \multicolumn{4}{|c|}{ Order Petromizoniformes - Lampreys } \\
\hline \multicolumn{4}{|c|}{ Family Petromyzonidae - Lampreys } \\
\hline $\begin{array}{c}\text { Genus } \\
\text { Eudontomyzon }\end{array}$ & $\begin{array}{l}\text { Eudontomyzon mariae - } \\
\text { Ukrainian brook lamprey }\end{array}$ & $\mathrm{Ab}$ & $1 / 1$ \\
\hline \multicolumn{4}{|c|}{ CLASS OSTEICHTHYES - BONY FISHES } \\
\hline \multicolumn{4}{|c|}{ Order Acipenseriformes - Sturgeons } \\
\hline \multicolumn{4}{|c|}{ Family Acipenseridae - Sturgeons } \\
\hline Genus Huso & Huso huso - beluga & $\mathrm{Ab}$ & $1 / 0$ \\
\hline \multirow{4}{*}{ Genus Acipenser } & $\begin{array}{c}\text { Acipenser nudiventris - thorn } \\
\text { sturgeon }\end{array}$ & $\mathrm{Ab}$ & $0 / 0$ \\
\hline & Acipenser ruthenus - sterlet & $\mathrm{Ab}$ & $1 / 2$ \\
\hline & $\begin{array}{c}\text { Acipenser güldenstädtii- } \\
\text { russian sturgeon }\end{array}$ & $\mathrm{Ab}$ & $2 / 0$ \\
\hline & $\begin{array}{c}\text { Acipenser stellatus - starred } \\
\text { sturgeon }\end{array}$ & $\mathrm{Ab}$ & $1 / 0$ \\
\hline \multicolumn{4}{|c|}{ Family Polyodontidae - Paddlefish } \\
\hline Genus Polyodon & $\begin{array}{l}\text { Polyodon spatuta- } \\
\text { paddlefish }\end{array}$ & Ada & $-/(1)$ \\
\hline \multicolumn{4}{|c|}{ Order Clupeiformes - Herrings } \\
\hline \multicolumn{4}{|c|}{ Family Clupeidae - Herrings } \\
\hline \multirow[t]{2}{*}{ Genus Alosa } & $\begin{array}{c}\text { Alosa pontica - Black Sea } \\
\text { shad }\end{array}$ & Adi & $-/(3)$ \\
\hline & Alosa caspia-Caspian shad & Adi & $-/(1)$ \\
\hline Genus Clupeonella & $\begin{array}{c}\text { Clupeonella cultriventris - } \\
\text { Black Sea sprat }\end{array}$ & Adi & $-/(-)$ \\
\hline \multicolumn{4}{|c|}{ Order Esociformes - Pikes } \\
\hline \multicolumn{4}{|c|}{ Family Esocidae - Pikes } \\
\hline Genus Esox & Esox lucius - northern pike & $\mathrm{Ab}$ & $-1-$ \\
\hline
\end{tabular}


Continuation of Table 4

\begin{tabular}{|c|c|c|c|}
\hline 1 & 2 & 3 & 4 \\
\hline \multicolumn{4}{|c|}{ Family Cyprinidae -Carps } \\
\hline \multirow{3}{*}{ Genus Rutilus } & Rutilus rutilus - roach & $\mathrm{Ab}$ & $-1-$ \\
\hline & $\begin{array}{l}\text { Rutilus rutilus heckeli - } \\
\text { common roach }\end{array}$ & Ada & $-/(-)$ \\
\hline & $\begin{array}{l}\text { Rutilus frisii-Black Sea } \\
\text { roach }\end{array}$ & $\mathrm{Ab}$ & $1 / 0$ \\
\hline \multirow{4}{*}{ Genus Leuciscus } & $\begin{array}{c}\text { Leuciscus leuciscus - } \\
\text { common dace }\end{array}$ & $\mathrm{Ab}$ & $2 / 2$ \\
\hline & $\begin{array}{l}\text { Leuciscus cephalus - } \\
\text { European chub }\end{array}$ & $\mathrm{Ab}$ & $-1-$ \\
\hline & $\begin{array}{c}\text { Leuciscus borystenicus - } \\
\text { Black Sea chub }\end{array}$ & $\mathrm{Ab}$ & -13 \\
\hline & Leuciscus idus - ide & $\mathrm{Ab}$ & -12 \\
\hline Genus Eupallassella & $\begin{array}{c}\text { Eupallassella percnurus - } \\
\text { lake minnow }\end{array}$ & $\mathrm{Ab}$ & $1 / 1$ \\
\hline Genus Scardinius & $\begin{array}{c}\text { Scardinius erythrophthalmus } \\
\text { - common rudd }\end{array}$ & $\mathrm{Ab}$ & $-1-$ \\
\hline $\begin{array}{c}\text { Genus } \\
\text { Ctenopharyngodon }\end{array}$ & $\begin{array}{c}\text { Ctenopharyngodon idella- } \\
\text { grass carp }\end{array}$ & Ada & $-/(-)$ \\
\hline Genus Aspius & Aspius aspius - asp & $\mathrm{Ab}$ & $-1-$ \\
\hline Genus Leucaspius & $\begin{array}{c}\text { Leucaspius delineatus - } \\
\text { sunbleak }\end{array}$ & $\mathrm{Ab}$ & $-1-$ \\
\hline Genus Tinca & Tinca tinca - tench & $\mathrm{Ab}$ & $-1-$ \\
\hline $\begin{array}{c}\text { Genus } \\
\text { Chondrostoma }\end{array}$ & $\begin{array}{c}\text { Chondrostoma nasus - } \\
\text { common nase }\end{array}$ & $\mathrm{Ab}$ & $-/ 1$ \\
\hline $\begin{array}{c}\text { Genus } \\
\text { Pseudorasbora } \\
\end{array}$ & $\begin{array}{c}\text { Pseudorusbora parva - stone } \\
\text { moroko }\end{array}$ & Adi & $-/(-)$ \\
\hline Genus Gobio & Gobio gobio - gudgeon & $\mathrm{Ab}$ & $-/ 2$ \\
\hline $\begin{array}{c}\text { Genus } \\
\text { Romanogobio }\end{array}$ & $\begin{array}{c}\text { Romanogobio albipinnatus } \\
\text { belingi - Dnieper whitefin } \\
\text { gudgeon }\end{array}$ & Adi & $-/(0)$ \\
\hline Genus Barbus & $\begin{array}{c}\text { Barbus barbus borystenicus - } \\
\text { Dnieper barbel }\end{array}$ & $\mathrm{Ab}$ & $1 / 0$ \\
\hline $\begin{array}{c}\text { Genus } \\
\text { Chalcalburnus }\end{array}$ & $\begin{array}{l}\text { Chalcalbunus chalcoides } \\
\text { mento - Caspian shemaya }\end{array}$ & Adi & $2 /(0)$ \\
\hline Genus Alburnus & Alburnus alburnus - bleak & $\mathrm{Ab}$ & $-1-$ \\
\hline Genus Alburnoides & $\begin{array}{l}\text { Alburnoides bipunctatus } \\
\text { rossicus - riffle minnow }\end{array}$ & $\mathrm{Ab}$ & $1 / 1$ \\
\hline Genus Blicca & Blicca bjorkna - silver bream & $\mathrm{Ab}$ & $-1-$ \\
\hline \multirow{3}{*}{ Genus Abramis } & Abramis brama - bream & $\mathrm{Ab}$ & $-1-$ \\
\hline & $\begin{array}{c}\text { Abramis sapa - white-eye } \\
\text { bream }\end{array}$ & $\mathrm{Ab}$ & 2 \\
\hline & $\begin{array}{c}\text { Abramis ballerus - carp } \\
\text { bream }\end{array}$ & $\mathrm{Ab}$ & $-/ 3$ \\
\hline Genus Vimba & $\begin{array}{c}\text { Vimba vimba natio carinata } \\
\text { - vimba }\end{array}$ & $\mathrm{Ab}$ & $-/ 1$ \\
\hline Genus Pelecus & Pelecus cultratus - sablefish & $\mathrm{Ab}$ & $-1-$ \\
\hline Genus Rhodeus & $\begin{array}{l}\text { Rhodeus amarus - European } \\
\text { bitterling }\end{array}$ & $\mathrm{Ab}$ & $-1-$ \\
\hline
\end{tabular}


Continuation of Table 4

\begin{tabular}{|c|c|c|c|}
\hline 1 & $\mathbf{2}$ & 3 & 4 \\
\hline \multirow{3}{*}{ Genus Carassius } & $\begin{array}{c}\text { Carassius carassius - } \\
\text { crucian carp }\end{array}$ & $\mathrm{Ab}$ & $2 / 2$ \\
\hline & & & \\
\hline & $\begin{array}{c}\text { Carassius auratus gibelio- } \\
\text { silver Prussian carp }\end{array}$ & Ada & $-/(-)$ \\
\hline Genus Cyprinus & $\begin{array}{c}\text { Cyprinus carpio - } \\
\text { European carp }\end{array}$ & $\mathrm{Ab}$ & $-1-$ \\
\hline $\begin{array}{c}\text { Genus } \\
\text { Hypophthalmichthys }\end{array}$ & $\begin{array}{l}\text { Hipophthalmichthys molitrix } \\
\text { - silver carp }\end{array}$ & Ada & $-/(-)$ \\
\hline Genus Aristichthys & $\begin{array}{c}\text { Aristichthys nobilis - bighead } \\
\text { carp }\end{array}$ & Ada & $-/(-)$ \\
\hline \multicolumn{4}{|c|}{ Family Balitoridae } \\
\hline Genus Barbatula & $\begin{array}{c}\text { Barbatula barbatula - stone } \\
\text { loach }\end{array}$ & $\mathrm{Ab}$ & $-/ 3$ \\
\hline \multicolumn{4}{|c|}{ Family Cobitidae } \\
\hline Genus Cobitis & Cobitis taenia - spined loach & $\mathrm{Ab}$ & $-1-$ \\
\hline Genus Misgurnus & $\begin{array}{c}\text { Misgurnus fossilis - } \\
\text { European weatherfish } \\
\end{array}$ & $\mathrm{Ab}$ & $-/ 3$ \\
\hline \multicolumn{4}{|c|}{ Order Siluriformes - European Wels } \\
\hline \multicolumn{4}{|c|}{ Family Siluridae - European Wels } \\
\hline Genus Silurus & $\begin{array}{c}\text { Silurus glanis - European } \\
\text { catfish }\end{array}$ & $\mathrm{Ab}$ & $-1-$ \\
\hline \multicolumn{4}{|c|}{ Family Ictaluridae -Ictalurids } \\
\hline Genus Ictalurus & $\begin{array}{l}\text { Ictalurus punctatus - } \\
\text { Channel catfish } \\
\end{array}$ & Ada & $-/(-)$ \\
\hline \multicolumn{4}{|c|}{ Order Anguilliformes - Eels } \\
\hline \multicolumn{4}{|c|}{ Family Anguillidae -Eels } \\
\hline Genus Anguilla & $\begin{array}{c}\text { Anguilla anguilla }- \text { European } \\
\text { eel }\end{array}$ & $\mathrm{Ab}$ & $-/ 1$ \\
\hline \multicolumn{4}{|c|}{ Order Mugiliformes - Mullets } \\
\hline \multicolumn{4}{|c|}{ Family Atherinidae - Silverside } \\
\hline Genus Atherina & $\begin{array}{c}\text { Atherina boyeri-big-scale } \\
\text { sand smelt }\end{array}$ & Adi & $-/(-)$ \\
\hline \multicolumn{4}{|c|}{ Order Cyprinodontiformes - Toothcarps } \\
\hline \multicolumn{4}{|c|}{ Family Poeciliidae - Poeciliidae Fishes } \\
\hline Genus Gambusia & $\begin{array}{l}\text { Gambusia holbrooki- } \\
\text { eastern mosquitofish }\end{array}$ & Ada & $-/(0)$ \\
\hline \multicolumn{4}{|c|}{ Order Gadiformes - Gadiformes } \\
\hline \multicolumn{4}{|c|}{ Family Lotidae - Lings } \\
\hline Genus Lota & Lota lota - burbot & $\mathrm{Ab}$ & $2 / 2$ \\
\hline \multicolumn{4}{|c|}{ Order Gasterosteiformes - Sticklebacks } \\
\hline \multicolumn{4}{|c|}{ Family Gasterosteidae - Sticklebacks } \\
\hline Genus Pungitius & $\begin{array}{l}\text { Pungitius platigaster- } \\
\text { Ukrainian stickleback }\end{array}$ & Аб & $-1-$ \\
\hline Genus Gasterosteus & $\begin{array}{l}\text { Gasterosteus aculeatus - } \\
\text { three-spined stickleback }\end{array}$ & Adi & $-/(3)$ \\
\hline \multicolumn{4}{|c|}{ Order Syngnathiformes - Pipefishes } \\
\hline
\end{tabular}


End of Table 4

\begin{tabular}{|c|c|c|c|}
\hline 1 & 2 & 3 & 4 \\
\hline \multicolumn{4}{|c|}{ Family Syngnathidae - Pipefishes } \\
\hline Genus Syngnathus & $\begin{array}{c}\text { Syngnathus abaster - black-striped } \\
\text { pipefish }\end{array}$ & Adi & $-/(-)$ \\
\hline \multicolumn{4}{|c|}{ Order Perciformes - Percids } \\
\hline \multicolumn{4}{|c|}{ Family Centrarchidae - Sunfishes } \\
\hline Genus Lepomis & Lepomis gibbosus - common sunfish & Adi & $-/(-)$ \\
\hline \multicolumn{4}{|c|}{ Family Percidae - Perches } \\
\hline \multirow{2}{*}{$\begin{array}{c}\text { Genus } \\
\text { Stizostedion } \\
\end{array}$} & Stizostedion lucioperca - Zander & $\mathrm{Ab}$ & $-1-$ \\
\hline & Stizostedion volgense - Volga zander & Adi & $1 /(1)$ \\
\hline Genus Perca & Perca fluviatilis - river perch & $\mathrm{Ab}$ & $-1-$ \\
\hline Genus Percarina & $\begin{array}{c}\text { Percarina demidoffi-common } \\
\text { percarina }\end{array}$ & Adi & $3 /(4)$ \\
\hline \multirow{2}{*}{$\begin{array}{c}\text { Genus } \\
\text { Gymnocephalus }\end{array}$} & Gymnocephalus cernuus - Ruffe & $\mathrm{Ab}$ & $-1-$ \\
\hline & Gymnocephalus acerinus - Don ruffe & $\mathrm{Ab}$ & $1 / 0$ \\
\hline \multicolumn{4}{|c|}{ Family Gobiidae - Goby } \\
\hline $\begin{array}{c}\text { Genus } \\
\text { Knipowitschia }\end{array}$ & $\begin{array}{c}\text { Knipowitschia longecaudata } \text { - longtail } \\
\text { dwarf goby }\end{array}$ & Adi & $-/(-)$ \\
\hline $\begin{array}{c}\text { Genus } \\
\text { Knipowitschia }\end{array}$ & $\begin{array}{l}\text { Knipowitschia caucasica } \\
\text { Caucasian dwarf goby }\end{array}$ & Adi & $-/(-)$ \\
\hline \multirow{4}{*}{ Genus Neogobius } & Neogobius melanostomus - round goby & Adi & $-/(-)$ \\
\hline & Neogobius kessleri-bighead goby & Adi & $-/(-)$ \\
\hline & Neogobius fluviatilis - monkey goby & $\mathrm{Ab}$ & $-/(-)$ \\
\hline & Neogobius ratan - ratan goby & Adi & $-/(-)$ \\
\hline \multirow{2}{*}{$\begin{array}{c}\text { Genus } \\
\text { Mesogobius }\end{array}$} & $\begin{array}{c}\text { Mesogobius gymnotrachelus - racer } \\
\text { goby }\end{array}$ & Adi & $-/(-)$ \\
\hline & $\begin{array}{c}\begin{array}{c}\text { Mesogobius batrachocephalus - knout } \\
\text { goby }\end{array} \\
\end{array}$ & Adi & $-/(-)$ \\
\hline $\begin{array}{c}\text { Genus } \\
\text { Proterorhinus }\end{array}$ & $\begin{array}{c}\text { Proterorhinus marmoratus - tube- } \\
\text { nosed goby }\end{array}$ & $\mathrm{Ab}$ & $-/(-)$ \\
\hline $\begin{array}{c}\text { Genus } \\
\text { Benthophiloides } \\
\end{array}$ & $\begin{array}{l}\text { Benthophiloides brauneri - Brauner's } \\
\text { tadpole-goby }\end{array}$ & Adi & $3 /(3)$ \\
\hline $\begin{array}{c}\text { Genus } \\
\text { Benthophilus }\end{array}$ & Benthophilus stellatus - starry goby & $\mathrm{Ab}$ & $2 / 2$ \\
\hline
\end{tabular}

Note. Ab-indigenous species, Ada-alien species (acclimatized species or in the process of acclimatization), Adi - alien species, naturally invasive (self-colonized); 0 - extincted species, 1 - disappearing species, 2 - sensitive species, 3 - rare species, 4 - indeterminated status; 5 - common species; 6 -dominant species. In parentheses the status of alien species listed. Red Data Book of Ukraine (2009) ${ }^{13}$; Red Data Book of Dnipropetrovsk region (2011) ${ }^{14}$.

At the present time, 8 species of indigenous fishes extincted in the fauna of water bodies in Steppe zone. These are rheophils that «came

13 Червона книга України. Тваринний світ: за ред. І. А. Акімова. К.: Глобалконсалтінг, 2009. 600 с.

14 Червона книга Дніпропетровської області (Тваринний світ): за ред. О.Є. Пахомова. Дніпропетровськ: ТОВ «Новий Друк», 2011. 488 с. 
out» from the structure of ichtyocomplexes after regulation of Dnieper River within Zaporizhzhya and New Kakhovka regions ${ }^{15}$.

Gone are such valuable sturgeon fishes as beluga, russian sturgeon, thorn sturgeon, starred sturgeon; Black Sea salmon (Salmons) and Dnieper madder (Carps), Dnieper (Perches) due to the middle river flow regulation of Dnieper River (within Kremenchuk and Kamyanske area). These native species that were widespread and normal such as lake minnow, ide, riffle minnow, stone loach, European eel, burbot, switched to the rare and disappearing species.

Native species such as common dace, asp, common nase, white-eye bream, carp bream, vimba, sablefish, may recieved a state of rare, vulnerable, and disappearing species.

At present, 12 species of Cyclostomes and fish within Prydniprov'ya are listed in the Red Data Book of Ukraine (2009): Ukrainian lamprey Eudontomyzon mariae, sterlet Acipenser ruthenus, riffle minnow Alburnoides bipunctatus rossicus, common dace Leuciscus leuciscus, lake minnow Eupallasella persnurus, crucian carp Carassius carassius, burbot Lota lota, Volga zander Sander volgensis, Don ruffe Gymnocephalus acerinus, percarina Percarina demidoffii, Brauner's tadpole-goby Benthophiloides brauneri, starry goby Benthophilus stellatus.

It should be noted that the Berne Convention (III) Amendments included the species numbers of that are not of concern in conditions of water bodies of Steppe zone in Ukraine, but with continuing of deterioration of the river status they may be candidates to the Red Regional Lists, follow to Red Data Book of Ukraine (indigenous fish as silver bream, spined loach, catfish common; self-colonized as threespined stickleback, black-stripped pipefish, bighead goby, etc.).

\section{The current state of the region's fisheries}

Six specialised fish farms, fish farms belonging to the former agricultural sector and small producers are engaged in the commercial fish-breeding in ponds in the region. Specialised fish farms use an area of about 2 thousand hectares for commercial fish-breeding, from which they

15 Новіцький Р.О., Губанова Н.Л. Трансформація іхтіоценозу Дніпровського (Запорізького) водосховища внаслідок зарегулювання p. Дніпро. Вісник Дніпропетровського державного аграрного університету. 2016. № 4 (42). C. 126-132. http://ojs.dsau.dp.ua/index.php/vestnik/article/view/806 
receive 1.5-2 thousand tons of commercial fish. As compared with the 1980s, fish production in almost all fish farms decreased by 2-4 times.

The state of fish farming in the region cannot be objectively assessed due to the lack of proper information on its implementation. At the regional level there is also no authority for coordinating the work of farms with the State Department of Fisheries. During the modern period, 377 farms have 12.8 thousand hectares of water resources in their use on a leasehold basis, of which 10.8 thousand hectares (85\%) are used for fish breeding. Subject to all regulatory and technological requirements and research-based stocking of farm reservoirs, these farms areas can produce about 10.5 thousand tons of high quality fish products. The fish capacity of most rented ponds is much lower than the fish capacity of specialised fish farms (15-30 times), that is, their use is ineffective, although the total ponds farm stock is quite significant. In compliance with all regulatory and technological requirements and scientifically grounded regime of stocking agricultural reservoirs with fish, up to 3-5 thousand tons of high-quality fish products can be obtained on their areas.

In recent years, the fish industry of the region has undergone a number of significant changes, which are conditioned by the industry transition to market relations. Some of the farms failed to adapt for operation in new economic conditions and became unprofitable. The decline of production is observed in almost all fish farms, the catches of fish decreased almost 2-4 times.

Due to the high cost of granulated fish fodder, commercial fish breeding in almost all fish farms is carried out only at the expense of the natural food supply. The forced transition from intensive fish breeding technology to feeding resulted in a drop in fish capacity of feeding ponds from 18-22 to 7-10, and in some fish farms - up to 3-5 centners per hectare. The average weight of the commodity two-year-old fish is 250$300 \mathrm{~g}$ versus standard $450-500 \mathrm{~g}$. This causes significant problems in selling fish products. Moreover, in recent years, the prime cost of commodity fish has increased significantly. The reasons for this include the increase in the cost of artificial fodder, the high price of natural water and electric power. Fish farms are forced to store the volume of collected water and grow fish without the water exchange in the ponds, which leads to deterioration of the hydrochemical state of reservoirs and, as a consequence, the delayed fish growth and the increase in their cost.

It should also be noted that the low level of veterinary and sanitary and preventive measures in fish-breeding in fish farms, and especially in rented farmer ponds. As a result, such dangerous diseases of fish as 
red spot, saprolegniosis, white spot, lerniosis, argulosis, etc. has become more and more frequent. Their distribution is also caused by uncontrolled transport of fish between fish farms and farmer ponds. Diseases often cause mass fish mortality and deteriorate quality commodity indicators.

\section{CONCLUSIONS}

For the successful implementation of the Strategy, it is necessary to make an inventory of fishery water bodies, develop passports of water bodies and modes of their use. It is necessary to monitor the local ichthyofauna, the influence of natural and man-made factors on it. It is proposed to provide a continuous analysis of the volume of IUU fishing in the water bodies of the region. It is necessary to consider the issues of increasing the bioresource potential of water bodies, justified introduction of valuable species of fish and invertebrates. It is necessary to organize the production and sale of balanced, complete feed.

To effectively control the activities of commercial fishing, the withdrawal of aquatic biological resources, and the prohibition of trade in biological resources without a state certificate, it is planned to introduce an electronic system «E-fish». It is necessary to control the development of amateur fishing in the region, support fishing tourism, and introduce a single «Fisherman's Ticket».

\section{SUMMARY}

The section is devoted to the problem of the complex use of biological resources of water bodies in Central-Eastern Ukraine. The authors propose ways of a more complete use of regional biological resources. It is noted that the potential of the fish industry in the Dnipropetrovsk region is significant, but today it is realized only by $30 \%$. According to the authors, in 5 years it is possible to increase the volume of fish production by 5 times. The authors propose for discussion the Strategy for the development of fisheries in the Dnipropetrovsk region. The main goal of the Program is to create conditions for the development of fisheries, ensuring its competitiveness, providing the population of the region with high-quality fish products. Specific measures for the implementation of the Program are proposed, ways of achieving the goal are substantiated. 


\section{References}

1. Гринжевський М.В. Аквакультура України. К., 1998. 364 с.

2. Новіцький Р. О. Масштаби, спрямованість та наслідки інвазій чужорідних видів риб у дніпровські водосховища. Автореф. дис.... д-р біол. наук: 03.00.10. Київ: ІГ НАН України, 2019. 41 с.

3. Сухойван П.Г., Вятчанина Л.И. Рыбное население и его продуктивность. $B$ кн.: Беспозвоночные и рыбы Днепра и его водохранилищ. К.: Наукова думка, 1989. С. 136-173.

4. Dvoretskyi A. I., Bajdak L. A. Fisheries development strategy of Dnipropetrovsk region. Science and technology bulletin of biosafety and environmental control of Agro-industrial complex. 2018. Vol. 6 (1). P. 6-14.

5. Запорожское водохранилище / А.И. Дворецкий, Ф. П. Рябов, Г.П. Емец и др. Д.: Изд-во ДНУ, 2000. 172 с.

6. Бурмакин Е. В. Акклиматизация пресноводных рыб в СССР. Известия ГосНИОРХ. 1963. Т. 53. С. 2-317.

7. Вовк П.С., Стеценко Л.И. Рыбы-фитофаги в экосистеме водохранилищ. К.: Наук. думка, 1985. 136 с.

8. Яковенко В. О., Дворецький А. І. Зоопланктон Дніпровського водосховища. Дніпропетровськ: Гамалія, 2012. 254 с.

9. Yakovenko V., Fedonenko O., Tushnytska N. Zooplankton and zoobenthos of the Mokra Sura river. Rybohospodarska nauka Ukrainy. 2017. 42(4), 19-32 DOI: 10.15407/fsu2017.04.019

10.Біологічне різноманіття України. Дніпропетровська область. Круглороті (Cyclostomata). Риби (Pisces) / В. Л. Булахов, Р. О. Новіцький, О. Є. Пахомов, О. О. Христов. Д.: Вид-во Дніпропетр. ун-ту, 2008. 304 с.

11. Novitsky R. A., Hristov O. A., Kochet V. N., Bondarev D. L. Annotated list of fishes of the Dnieper Reservoir and its tributaries. Bulletin of DNU. Biology, Ecology. Issue 13, Vol. 1. Dnipropetrovsk: Publ. of DNU, 2005. P. 185-201.

12.Issues of the ecosystem services provided by animals under anthropogenic pressure within Ukrainian steppe: monogr. (2016). A. Y. Pakhomov et al. Vienna: East West Association for Advanced Studies and Higher Education GmbH. 160 p.

13. Червона книга України. Тваринний світ: за ред. І. А. Акімова. К.: Глобалконсалтінг, 2009. 600 с.

14. Червона книга Дніпропетровської області (Тваринний світ): за ред. О.С. Пахомова. Дніпропетровськ: ТОВ «Новий Друк», 2011. 488 c. 
15.Новіцький Р.О., Губанова Н. Л. Трансформація іхтіоценозу Дніпровського (Запорізького) водосховища внаслідок зарегулювання р. Дніпро. Вісник Дніпропетровського державного аграрного університету. 2016. № 4 (42). С. 126-132. http://ojs.dsau.dp.ua/index.php/vestnik/article/view/806

Information about the authors: Novitskyi Roman Oleksandrovych, Doctor of Biological Science, Professor, Head of the Department of Aquatic Bioresources and Aquaculture Dnipro State Agrarian and Economic University 25, Sergiy Efremov Street, 49600, Dnipro, Ukraine

Bajdak Leonid Andriyovych, Candidate of Historical Sciences, Senior Researcher

Dnipro State Agrarian and Economic University 25, Sergiy Efremov Street, 49600, Dnipro, Ukraine 